Relations industrielles

Industrial Relations

\title{
Index - volume $32-1977$
}

Volume 32, numéro 4, 1977

URI : https://id.erudit.org/iderudit/028840ar

DOI : https://doi.org/10.7202/028840ar

Aller au sommaire du numéro

Éditeur(s)

Département des relations industrielles de l'Université Laval

ISSN

0034-379X (imprimé)

1703-8138 (numérique)

Découvrir la revue

Citer ce document

(1977). Index - volume 32 - 1977. Relations industrielles / Industrial Relations, 32(4), 656-665. https://doi.org/10.7202/028840ar

Tous droits réservés (C Département des relations industrielles de l'Université Laval, 1977
Ce document est protégé par la loi sur le droit d'auteur. L’utilisation des services d'Érudit (y compris la reproduction) est assujettie à sa politique d'utilisation que vous pouvez consulter en ligne.

https://apropos.erudit.org/fr/usagers/politique-dutilisation/ 


\section{INDEX - VOL. $32-1977$}

\section{Index alphabétique des articles}

Absenteeism and Overtime: Double Jeopardy, by Al Mikalachki and D. C.

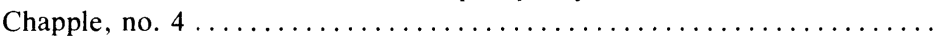

Absentéisme et surtemps, par Al Mikalachki et D. C. Chapple, no. 4........ Activité syndicale et autorisation préalable de congédier, congédiement pour,

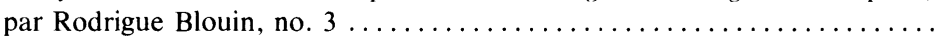
Aide sociale au Québec, un modèle de l'offre de travail des bénéficiaires de l',

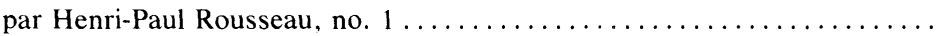

Analysis of Annual Turnover Rates for Canadian Union Presidents, an, by Gary N. Chaison and Joseph B. Rose, no. $4 \ldots \ldots \ldots \ldots \ldots \ldots \ldots$ Arbitrage des propositions finales et les compromis annuels, l', par James B.

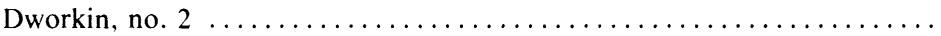
Arbitration and Intertemporal Compromise, Final Position by James B.

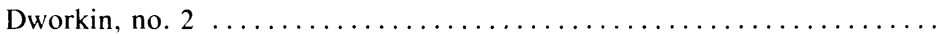
Associations d'employeurs dans l'industrie de la construction au Canada, les,

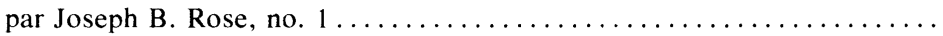
Benefit Preferences at Canadian National: New Evidence, Employee Pay and,

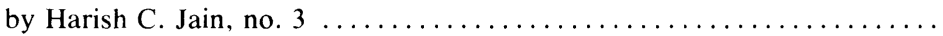
Bullock and the Aftermath, by Adolf Sturmthal, no. $3 \ldots \ldots \ldots \ldots \ldots \ldots$ Bullock et ses répercussions, le rapport, par Adolf Sturmthal, no. $3 \ldots \ldots \ldots$. . . Cadres canadiens-français, canadiens-anglais et américains, critères d'augmentations de salaires chez les, par Roland D. Thériault et Lee D. Dyer,

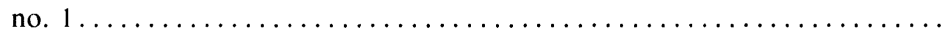

Canada, Candide-Cofor et la prévision de besoins en main-d'œuvre par occupation et par industrie au Canada, par Pierre-Paul Proulx, Luce Bourgault et

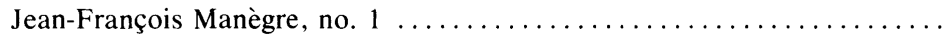
Canada, Collective Bargaining in the Public Service of by John C. Anderson and Thomas A. Kochan, no. $2 \ldots \ldots \ldots \ldots \ldots \ldots \ldots \ldots \ldots \ldots \ldots \ldots \ldots \ldots \ldots$

Canada, Construction Labour Relations Association in, by Joseph B. Rose,

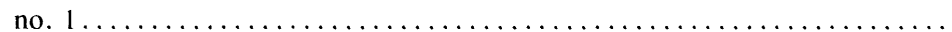

Canada' Forecasting Manpower Needs by Occupation and Industry in, by Pierre-Paul Proulx, Luce Bourgault and Jean-François Manègre, no. 1 ... Canada's Prices and Income Policy, the Estimate of Productivity Growth in, by Sidney $\mathrm{H}$. Ingerman and Ruth Rose-Lizie, no. $1 \ldots \ldots \ldots \ldots \ldots$ Canada: Theory and Evidence, the Rationale for Government Involvement in Manpower in, by Keith Newton, no. 3 ....................... Canadian National: New Evidence, Employee Pay and Benefit Preferences at,

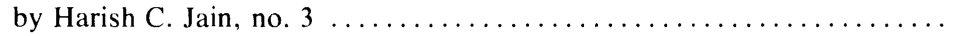
Canadians, Wage Differentials Between Native and Foreign Born, by B. B.

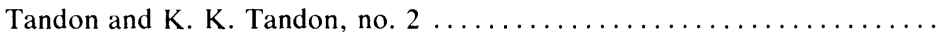
Candide-Cofor et la prévision de besoins en main-d'auvre par occupation et par industrie au Canada, par Pierre-Paul Proulx, Luce Bourgault et Jean-

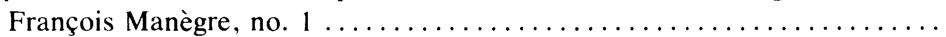
Centrales syndicales, le changement des présidents dans les, par Gary $\mathrm{N}$.

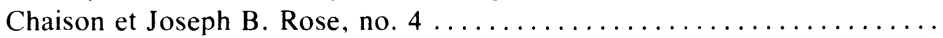

Christian Trade Unionism in France: A Left Socialist Experience, by E. M.

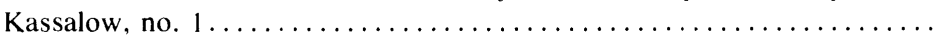


Collective Bargaining in the Public Service of Canada, by John C. Anderson

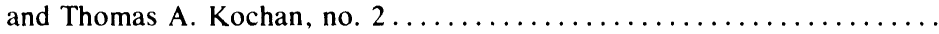

Collective Bargaining by Salaried Professionals, by George W. Adams, no. 2 . Collective Bargaining, Psychological Conflict Models: their Applicability to the

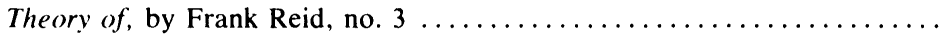

Comparative Manpower Strategies, by R. A. Jenness no. $1 \ldots \ldots \ldots \ldots \ldots$

Conflict Models: their Applicability to the Theory of Collective Bargaining,

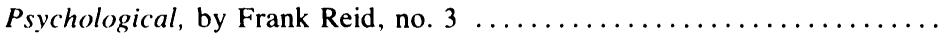

Conflits, les conséquences des mécanismes de solution des, par A. V. Subbarao,

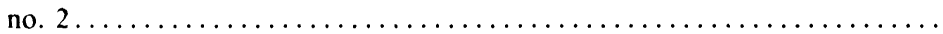

Congédiement pour activité syndicale et autorisation préalable de congédier,

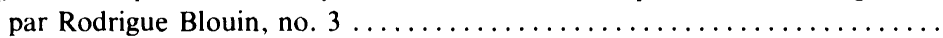

Congrès syndicaux, les obstacles à la démocratie dans les, par John C. Ander-

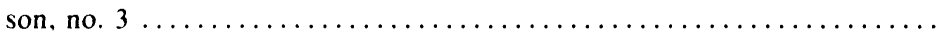

Conséquences des mécanismes de solution des conflits, les, par A. V. Subbarao,

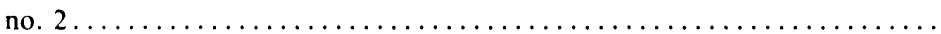

Construction Labour Relations Association in Canada, by Joseph B. Rose,

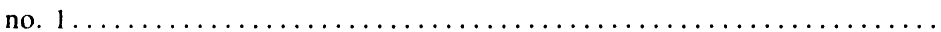

Construction au Canada, les associations d'employeurs dans l'industrie de la,

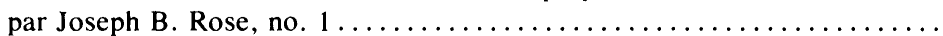

Consultation: un processus andragogique centré sur le client, la, par Hubert

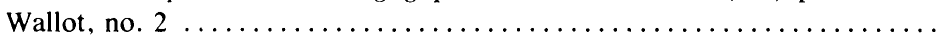

Contrat individuel de travail: l'affaire McGavin Toastmaster, l'effet de la grève

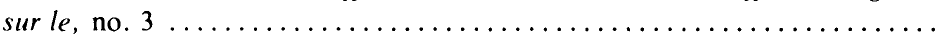

Contrôle et décontrôle des prix et des revenus, le, par Claude Montmarquette,

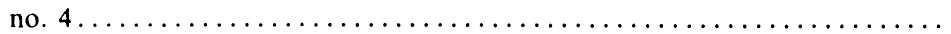

Controls: the American Experience, the Response of Wages to the Removal of,

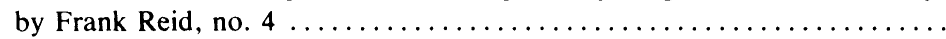

Changement des présidents dans les centrales syndicales, le, par Gary N. Chai-

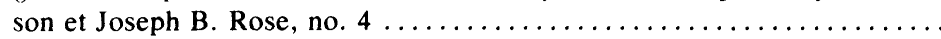

Christian Trade Unionism in France: A Left Socialist Experience, by E. M.

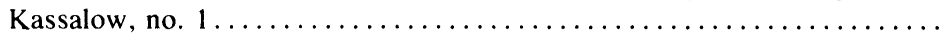

Critères d'augmentations de salaires chez les cadres canadiens-français, canadiens-anglais et américains, par Roland D. Thériault et Lee D. Dyer,

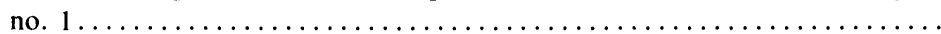

Democratic Decision Making, the Union Convention: an Examination of Limi-

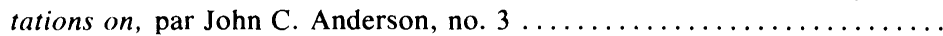

Démocratie dans les congrès syndicaux, les obstacles à la, par John C. Ander-

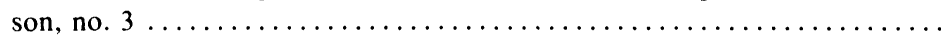

Détermination des salaires dans la fonction publique fédérale américaine: applicabilité au Québec, par Luc Bessette, no. $2 \ldots \ldots \ldots \ldots \ldots \ldots \ldots$

Développement des ressources humaines, fonction négligée par l'entreprise,

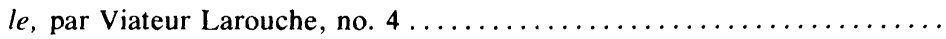

Différence de traitements entre autochtones et aubains, par B. B. Tandon et

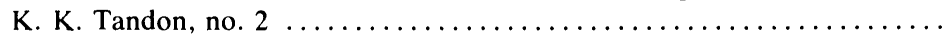

Dismissal for Union Activity and Advance Authorization to Dismiss, by

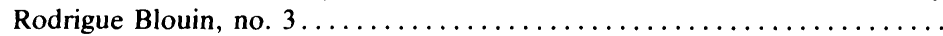

Dispute Resolution Processes in Negotiations, the Impact of the Two, by

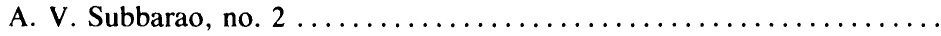

234-248

$184-200$

445-449

94-106

$445-449$

233-234

34-377

396-399

233-234

274-285

456-461

628-634

621-628

547-563

379-396

396-399

161-170

483-511

214-216

$277-279$

216-233 
Dispute Settlement, the Influence of Public Opinion in Labour-Management Relations and, by Stephen G. Peitchinis, no. $2 \ldots \ldots \ldots \ldots \ldots \ldots \ldots$

Divergence ou convergence du mouvement syndical et du mouvement coopératif des Caisses Desjardins, par Fernand Morin no. 2 .................

Economic Returns on Under-Graduate Fields of Study in Canadian Universities, 1961 to 1972, by Ozay Mehmet, no. $3 \ldots \ldots \ldots \ldots \ldots \ldots \ldots$

Effet de la grève sur le contrat individuel de travail: l'affaire McGavin Toastmaster, $l$ ', par Claude D'Aoust, no. $3 \ldots \ldots \ldots \ldots \ldots \ldots \ldots \ldots \ldots \ldots$

Employee Pay and Benefit Preferences at Canadian National: New Evidence,

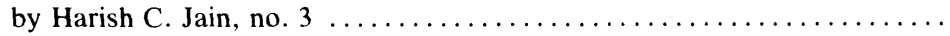

Employeurs dans l'industrie de la construction au Canada, les associations d',

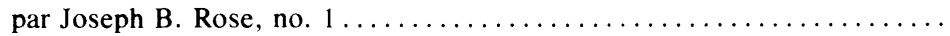

Estimate of Productivity Growth in Canada's Prices and Incomes Policy, by Sideney H. Ingerman and Ruth Rose-Lizée, no. $1 \ldots \ldots \ldots \ldots \ldots \ldots$ Étude comparative des stratégies en matières de politique de main-d'ceuvre,

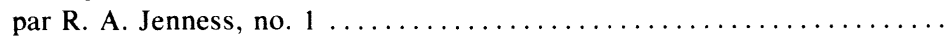

Évaluation du rendement: perceptions de l'employé, de son supérieur et de ses collègues, l', par Jean-Louis Bergeron no. $4 \ldots \ldots \ldots \ldots \ldots \ldots \ldots \ldots$

Factors Related to Performance Variation Among Logging-Machine Operators, by Richard T. Barth and Philip L. Cottell, no. $4 \ldots \ldots \ldots \ldots \ldots \ldots \ldots$

Field Officer, the Work of the Trade Union, by Roy J. Adams, no. $4 \ldots \ldots \ldots$. . . Final Position Arbitration and Intertemporal Compromise, by James B.

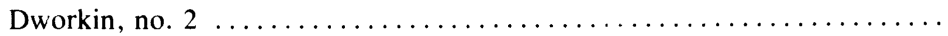

Fonction publique du Canada, la négociation collective dans la, par John C. Anderson et Thomas A. Kochan, no. 2 ......................

Fonction publique fédérale américaine: applicabilité au Québec, détermination

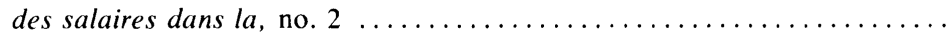

Fonction publique fédérale américaine: applicabilité au Québec, détermination des salaires dans la, par Luc Bessette, no. 2 ...................

Forecasting Manpower Needs by Occupation and Industry in Canada, by Pierre-Paul Proulx, Luce Bourgault, et Jean-François Manègre, no. 1 . ... France: A Left Socialist Experience, Christian Trade Unionism in, by E. M.

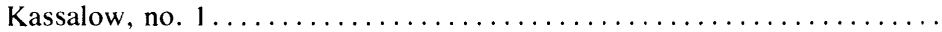

France: une expérience de socialisme de gauche, le syndicalisme chrétien en,

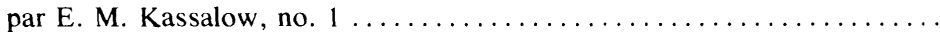
Government Involvement in Manpower Training in Canada: Theory and Evidence, the Rationale for, by Keith Newton, no. $3 \ldots \ldots \ldots \ldots \ldots$

Grève, l'injonction en temps de, par Fernand Morin, no. $3 \ldots \ldots \ldots \ldots \ldots$. Grève sur le contrat individuel de travail: l'affaire McGavin Toastmaster, l'effet de la, par Claude D'Aoust, no. 3 ....................... Hazardous Work, Labour Arbitration and the Refusal to Perform, by Ray

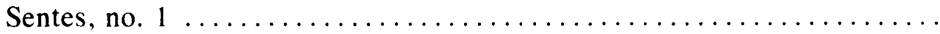
Human Resource Development, Personnel Training: The Cinderella in the Firm's Arsenal of, by Viateur Larouche, no. $4 \ldots \ldots \ldots \ldots \ldots \ldots \ldots$ Impact of the Two Dispute Resolutions Processes in Negociations, the, by

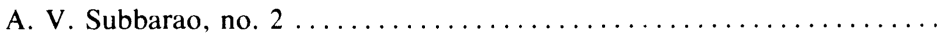

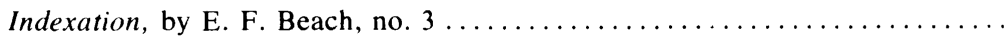
Influence of Public Opinion in Labour-Management Relations and Dispute Settlement, the, by Stephen G. Peitchinis, no. $2 \ldots \ldots \ldots \ldots \ldots \ldots \ldots$ Injonction en temps de grève, par Fernand Morin, no. $3 \ldots \ldots \ldots \ldots \ldots$ $268-274$ $262-268$ $321-337$ 456-461

$106-108$ 603-619 $566-589$ $514-528$ $250-260$

248-250

$161-170$

161-170

126- 127 
Job Vacancies, the Paradox of Unemployment and, Comment: Frank J. Reid;

Reply: Michael L. Skolnik and Farid Siddiqui, no. $1 \ldots \ldots \ldots \ldots \ldots$

Labor Supply of Low-Income Families on Québec, A Model of, by Bernard

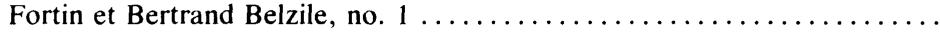

Labor Supply of Social Assistance Recipients in Québec, A Model of the, by

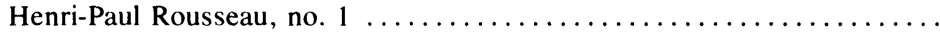

Labour Arbitration and the Refusal to Perform Hazardous Work, by Ray

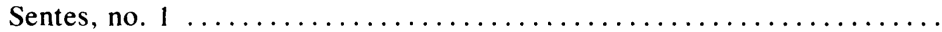

Low-Income Families on Québec, A Model of Labor Supply of, by Bernard

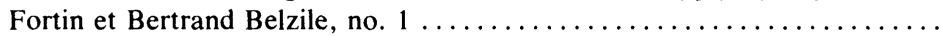

Main-d'euvre par occupation et par industrie au Canada, Candide-Cofor et la prévision de besoins en, par Pierre-Paul Proulx, Luce Bourgault et Jean-

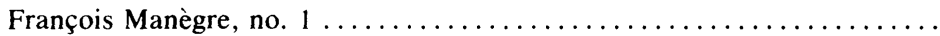

Managers, Salary Increase Criteria According to French Canadian, English Canadian and American, by Roland D. Thériault and Lee D. Dyer, no. 1 . Manpower Needs by Occupation and Industry in Canada, Forecasting, by Pierre-Paul Proulx, Luce Bourgault and Jean-François Manègre, no. 1 ...

Manpower Strategies, Comparative, by R. A. Jenness, no. $1 \ldots \ldots \ldots \ldots \ldots$ Manpower Training in Canada: Theory and Evidence, the Rationale for Government in, by Keith Newton, no. $3 \ldots \ldots \ldots \ldots \ldots \ldots \ldots \ldots \ldots$

Minimum Wages and the Political Process, by Jean-Luc Migué, no. 3........ Model of the Labor Supply of Social Assistance Recipients in Québec, a,

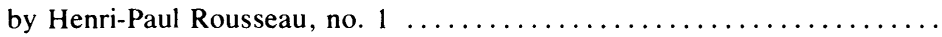

Model of Labor Supply of Low-Income Families on Québec, A, by Bernard

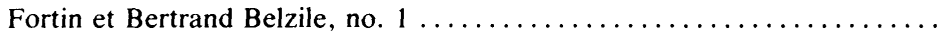
Modèle de l'offre de travail des bénéficiaires de l'aide sociale au Québec, un,

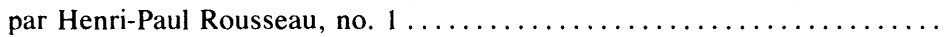

Modèle d'offre de travail des familles à faible revenu au Québec, un, par Bernard Fortin et Bertrand Belzile, no. $1 \ldots \ldots \ldots \ldots \ldots \ldots \ldots \ldots$ Mouvement coopératif des Caisses Desjardins, divergence ou convergence du

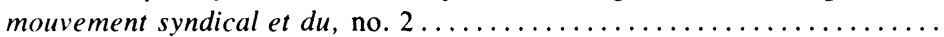

Mouvement syndical et du mouvement coopératif des Caisses Desjardins, divergence ou convergence du, par Fernand Morin, no. $2 \ldots \ldots \ldots \ldots$.

Multinationales, syndicats et, par Malcolm Warner et Riccardo Peccei, no. 2 ..

Multinationals, Towards "Participative", by Malcolm Warner and Riccardo Peccei, no. 2

Négociation collective chez les professionnels, la, par George W. Adams, no. 2

Négociation collective dans la fonction publique du Canada, la, par John C.

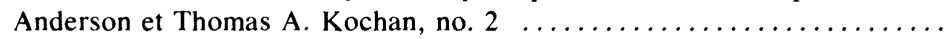

Negotiations, the Impact of the Two Dispute Resolution Processes, in by

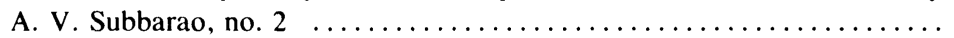
Obstacles à la démocratie dans les congrès syndicaux, les, par John C.

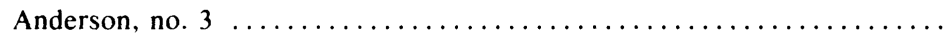

Offre de travail des familles à faible revenu au Québec, un modèle d', par

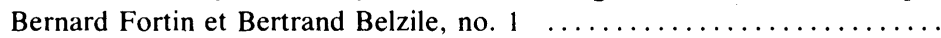

Offre de travail des bénéficiaires de l'aide sociale au Québec, un modèle de l', par Henri-Paul Rousseau, no. 1 ........................

Overtime: Double Jeopardy, Absenteeism and by Al Mikalachki and D. C. Chapple, no. 4 
Paradox of Unemployment and Job Vacancies, the, Comment: Frank J. Reid, Reply: Michael L. Skolnik and Farid Siddiqui, no. 1 ..........

"Participative" Multinationals, Towards, by Malcolm Warner and Riccardo

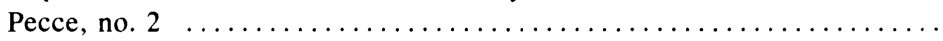

Performance et rendement chez des opérateurs de machines, par Richard

T. Barth et Philip L. Cottell, no. $4 \ldots \ldots \ldots \ldots \ldots \ldots \ldots \ldots \ldots \ldots$

Performance Variation Among Logging-Machine Operators, Factors Related

to, by Richard T. Barth and Philip L. Cottell, no. $4 \ldots \ldots \ldots \ldots \ldots$

Permanents syndicaux, la tâche des, par Roy J. Adams, no. $4 \ldots \ldots \ldots \ldots \ldots$

Politique de main-d'æuvre, étude comparative des stratégies en matière de,

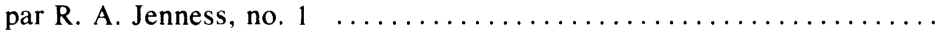

Présidents dans les centrales syndicales, le changement des, par Gary $\mathrm{N}$.

Chaison et Joseph B. Rose, no. 4 ........................

Prices and Incomes Policy, the Estimate of Productivity Growth in Canada's,

by Sidney $\mathrm{H}$. Ingerman and Ruth Rose-Lizée no. $1 \ldots \ldots \ldots \ldots \ldots$

Productivity Growth in Canada's Prices and Incomes Policy, the Estimate of,

by Sidney H. Ingerman and Ruth Rose Lizée, no. $1 \ldots \ldots \ldots \ldots \ldots$

Professionals, Collective Bargaining by Salaried, by George W. Adams,

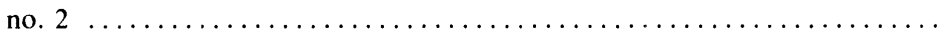

Propositions finales et les compromis annuels, l'arbitrage des, par James

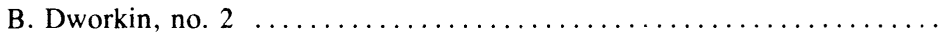

Psychological Conflict Models: their Applicability to the Theory of Collective

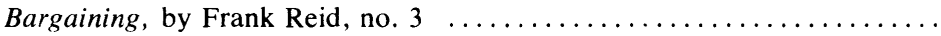

Public Opinion in Labour-Management Relations and Dispute Settlement, the

Influence of, by Stephen G. Peitchinis, no. $2 \ldots \ldots \ldots \ldots \ldots \ldots \ldots$

Public Service of Canada, Collective Bargaining in the by John C. Anderson

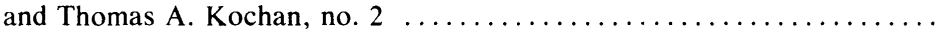

Québec, A Model of the Labor Supply of Low-Income Families on, by Bernard

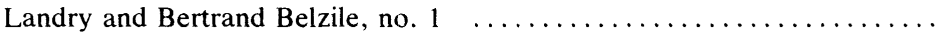

Québec, A Model of the Labor Supply of Social Assistance Recipients in,

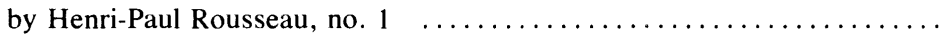

Québec, détermination des salaires dans la fonction publique fédérale américaine: applicabilité $a u$, par Luc Bessette, no. $2 \ldots \ldots \ldots \ldots \ldots \ldots \ldots$

Québec, un modèle d'offre de travail des familles à faible revenu au, par Bernard Fortin et Bertrand Belzile, no. 1 .....................

Québec, un modèle de l'offre de travail des bénéficiaires de l'aide sociale au,

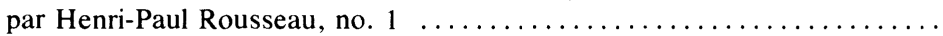

Rationale for Government Involvement in Manpower Training in Canada: Theory and Evidence, the, by Keith Newton, no. 3 ...............

Rendement économique des diverses disciplines dans les universités cana-

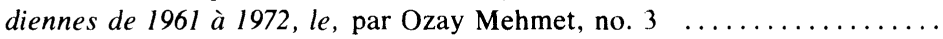

Rendement chez des opérateurs de machines, performance et, par Richard

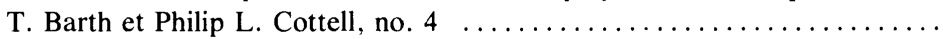

Rendement: perceptions de l'employé, de son supérieur et de ses collègues, l'évaluation $d u$, par Jean-Louis Bergeron, no. $4 \ldots \ldots \ldots \ldots \ldots \ldots \ldots$

Response of Wages to the Removal of Controls: The American Experience,

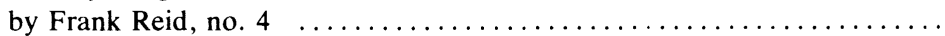

Ressources humaines, fonction négligée par l'entreprise, le développement

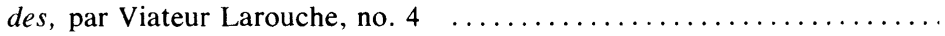

Revenu au Québec, un modèle d'offre de travail des familles à faible, par Bernard Fortin et Bertrand Belzile, no. 1 .....................

$566-584$

$566-584$

528-532

106-108

547-563

127-133

127-133

$184-200$

260-262

445-449

268-274

234-248

64-65

161-170

50-64

$399-414$

$337-340$

566-584

603-619

621-628

483-511 
Salaires chez les cadres canadiens-français, canadiens-anglais et américains, critères d'augmentations de, par Roland D. Thériault et Lee D. Dyer

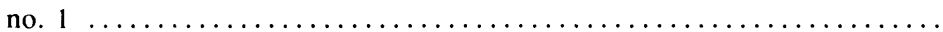

Salaires dans la fonction publique fédérale américaine: applicabilité au

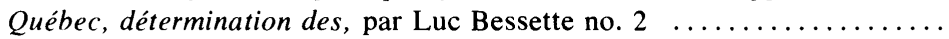

Salaire minimum ou quand le diable se fait moine, par Jean-Luc Migué, no. 3 .. Salary Determination in the US Federal Service: Applicability to Québec, by Luc Bessette, no. 2 ................................

Social Assistance Recipients in Québec, A Model of the Labor Supply of,

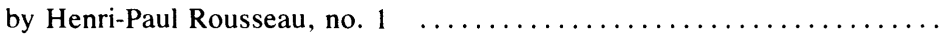

Socialisme de gauche, le syndicalisme chrétien en France: une expérience de,

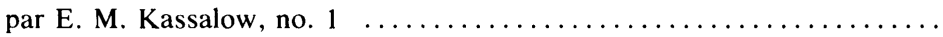

Socialist Experience, Christian Trade Unionism in France: A Left, by

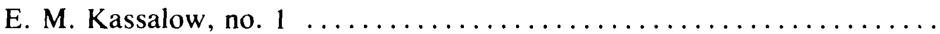

Strikes as Safety-Valve Institutions by Ran Chermesh, no. $4 \ldots \ldots \ldots \ldots \ldots$ Surtemps, absentéisme et, par Al Mikalachki et D. C. Chapple, no. 4 ....... Syndicalisme chrétien en France: une expérience de socialisme de gauche, le, par E. M. Kassalow, no. 1

Tâche des permanents syndicaux, la, par Roy J. Adams, no. 4 ............

Towards "Participative" Multinationals, by Malcolm Warner and Riccardo Peccei, no. 2

Trade Union Field Officer, the Work of the by Roy J. Adams, no. 4 .......

Trade Unionism in France: A Left Socialist Experience, Christian, by

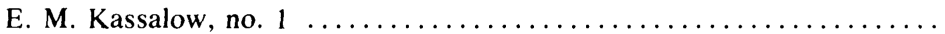

Training: the Cinderella in the Firm's Arsenal of Human Resource Development, Personnel by Viateur Larouche, no. 4 ..................

Traitements entre autochtones et aubains, différence de, par B. B. Tandon

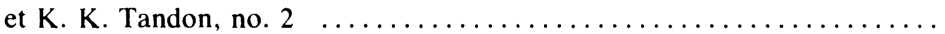

Turnover Rates for Canadian Union Presidents, an Analysis of Annual, by Gary N. Chaison and Joseph B. Rose, no. 4 ................

Under-Graduate Fields of Study in Canadian Universities 1961 to 1972, Economic Returns on, by Ozay Mehmet, no. $3 \ldots \ldots \ldots \ldots \ldots \ldots$

Unemployment and Job Vacancies, the Paradox of, Comment: Frank J. Reid; Reply: Michael L. Skolnik and Farid Siddiqui, no. 1 ..........

Union Activity and Advance Authorization to Dismiss, Dismissal for, by

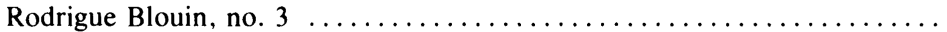

Union Convention: An Examination of Limitations on Democratic Decision Making, the, by John C. Anderson, no. $3 \ldots \ldots \ldots \ldots \ldots \ldots \ldots \ldots \ldots \ldots$

Union Presidents, An Analysis of Annual Turnover Rates for Canadian, by Gary N. Chaison and Joseph B. Rose, no. 4 ................

Universités canadiennes de 1961 à 1972, le rendement économique des diverses disciplines dans les, par Ozay Mehmet, no. 3 .............

Universities, 1961 to 1972, Economic Returns on Under-Graduate Fields of Study in Canadian, by Ozay Mehmet, no. 3 .................

Wage Differentials Between Native and Foreign Born Canadians, by B. B. Tandon and K. K. Tandon, no. 2 ...................... 202-214

Work of the Trade Union Field Officer, the, by Roy J. Adams, no. 4 ...... 514-528 


\section{Auteurs des ouvrages recensés}

ASHENFELTER, O. et J. BLUM (ed.) Evaluating the Labor-Market Effects of Social Programs (Jacques Saint-Laurent), no. $3 \ldots \ldots \ldots \ldots \ldots$

BARRY, Francine, Le travail de la femme au Québec: l'évolution de 1940

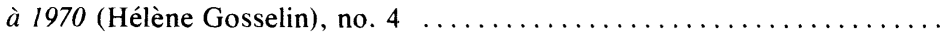

BÉLANGER, Laurent, Jean BOIVIN, Gilles DUSSAULT, Alain LAROCQUE (sous la direction de), Participation et négociation collective, (Dimitri

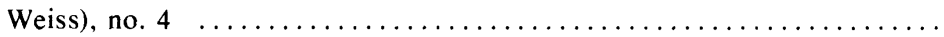

BOULARD, R., Louise H. CÔTÉ, S. GUIMOND et B. TURGEON, Les répercussions de l'horaire variable sur l'individu, (André Savoie), no. 3 ...

BURACK, Elmer H. et Robert D. SMITH, Personnal Management. A Human Resource System Approach, (Laurent Bélanger), no. 1 .............

CAZENEUVE, Jean (sous la direction de) La sociologie et les sciences de la

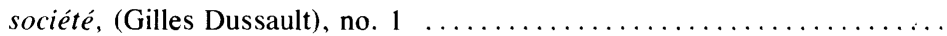

CHUNG, Joseph H., Cyclical Instability in Residential Construction, in

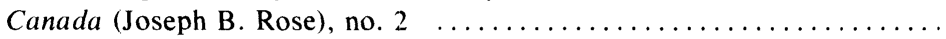

CONSEIL DES ARTS DU CANADA, Déontologie, rapport du groupe consultatif de déontologie, (Gilles Dussault), no. $2 \ldots \ldots \ldots \ldots \ldots \ldots \ldots$

CONSEIL ÉCONOMIQUE DU CANADA, Horizon 1982, quatorzième exposé

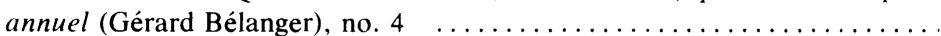

CONSEIL ÉCONOMIQUE DU CANADA Vivre ensemble, une étude des

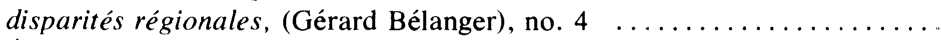

CÔTÉ, Louise $\mathrm{H}$. et Normande LEWIS, L'horaire variable au Québec:

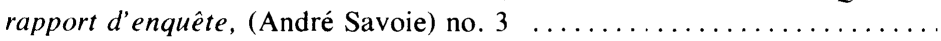

FERGUSON, R. H., Cost-of-Living Adjustments in Union-Management Agreements, (Jacques St-Laurent), no. $4 \ldots \ldots \ldots \ldots \ldots \ldots \ldots \ldots$

FRASER, R. D., Health Economics Symposium: Proceedings of the First

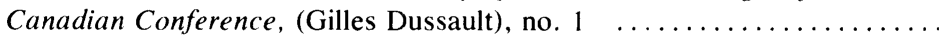

GUERTIN, Jean-Aimé, Jean-François GUILlOTEAU et Paul-Martel ROY, Analyse coûts-bénéfices de fermetures d'entreprises, (Bertrand Belzile). no. 4

GUNDERSON, Morley, Collective Bargaining in the Essential and Public

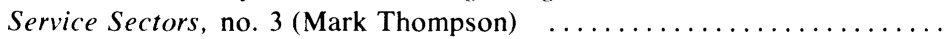

JAIN, H. C. et R. N. KANUNGO, Behavioral Issues in Management: the Canadian Context, (Laurent Bélanger), no. $3 \ldots \ldots \ldots \ldots \ldots \ldots$

LOWENBERG, Joseph J, Walter J. GERSHENFELD, H. J. GLASBEEK, B. A. HEPPLE, Kenneth F. WALKER, Compulsory Arbitration,

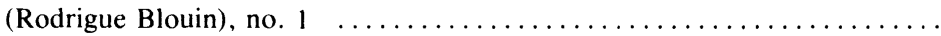

MARSH, Léonard, Report on Social Security for Canada 1943, (Bertrand

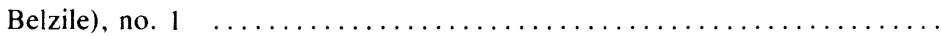

MINER, John B., The Human Constraint, the Coming Shortage of Managerial

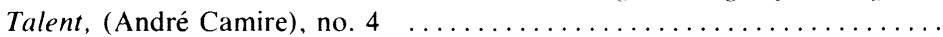

MITCHELl Daniel J. B. and Ross E, AZEVEDO, Wage Price Controls and Labor Market Distortions, (Jacques Saint-Laurent) no. 4 .........

MORRIS, James O, Bibliography of Industrial Relations in the Railroad

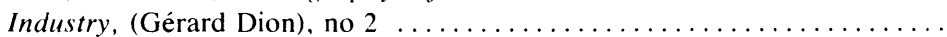

OCDE, L'insertion des jeunes dans la vie active, (Jean-Pierre Auger), no. 4 .. ONTARIO MINISTRY OF LABOUR, Equal Pay for Work of Equal Value, (Jacques Saint-Laurent), no. 3

$471-472$

$645-646$

636-639

$466-467$

146

146-147

287-288

286- 287

634-636

639-641

463-465

643

147-148

468-469

$470-471$

145-146

148-149

644-645

643-644

286

641-642

$469-470$ 
ROSOW, Jerome M. (Ed.) The Worker and the Job, (Maurice Lemelin),

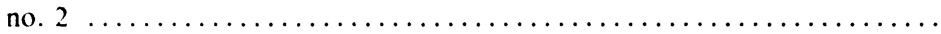

SANDBROOK, R and R. COHEN, The Development of an African Working

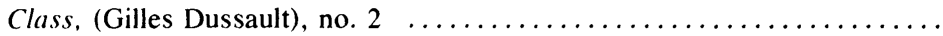

SAYLES, Léonard R, et Georges STRAUSS, Managing Human Resources,

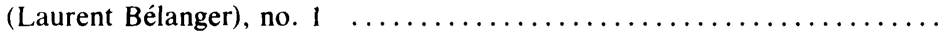

SUMMERS, Robert S., Collective Bargaining and Public Benefit Conferral:

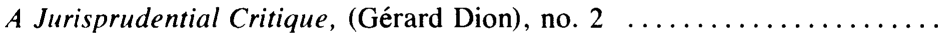

TANIMOTO, Helen, S., Guide to Statutory Provisions in Public Sector Bargaining Impasse Resolutions Procedures, (Gérard Dion), no. 3 ....

TESSIER, B. M., et B. TURGEON, L'horaire variable, rapport de la mission d'étude en Allemagne et en Suisse, (André Savoie) no. 3 ............

TURGEON, B. Les horaires variables: examen de la littérature, (André

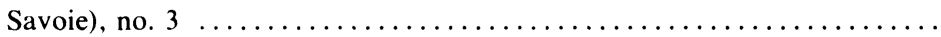

WATLEY, Arthur A, et Nelson L. KELLY, Personnel Management in Action: Skill Building Experiences, (Laurent Bélanger), no. 2 .........

WOOD, H. D. and P. KUMAR (ed.) The Current Industrial Relations Scene in Canada 1977, (Gérard Dion) no. 3 ........................

\section{Auteurs d'articles}

ADAMS, George W. Collective Bargaining by Salaried Professionals, no. 2 ..

$184-202$

ADAMS, Roy J., The Work of the Trade Union Field Officer, no. 4 ......... $514-528$

ANDERSON, John C. and Thomas A. KOCHAN, Collective Bargaining in the Public Service of Canada, no. 2

234-250

ANDERSON, John C., The Union Convention: An Examination of Limitations

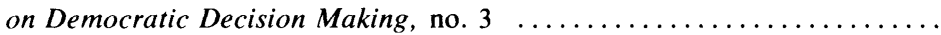

BARTH, Richard T, and Philip L. COTTELL, Factors Related to Performance Variation Among Logging-Machine Operators, no. $4 \ldots \ldots \ldots \ldots$

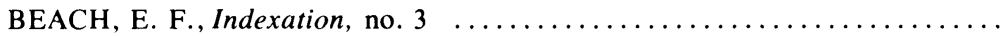

BELZILE, Bertrand et Bernard FORTIN, Un modèle d'offre de travail des

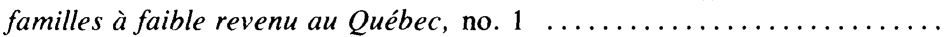

BERGERON, Jean-Louis, L'évaluation du rendement: perceptions de

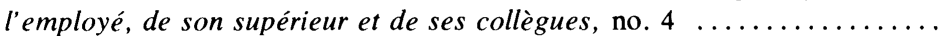

BESSETTE, Luc, Détermination des salaires dans la fonction publique fédérale américaine: applicabilité au Québec, no. $2 \ldots \ldots \ldots \ldots \ldots . . \ldots \ldots$

BLOUIN, Rodrigue, Congédiement pour activité syndicale et autorisation

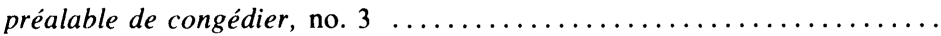

BOURGAULT, Luce, Pierre-Paul PROULX et Jean-François MANEGRE, Candide-Cofor et la prévision de besoins en main-d' euvre par occupation

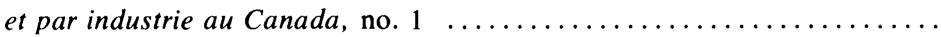

CHAISON, Gary N. and Joseph B. ROSE, An Analysis of Annual Turnover Rates for Canadian Union Presidents, no. 4 ...................

CHAPPLE, D. C. and Al. MIKALACHKI, Absenteeism and Overtime:

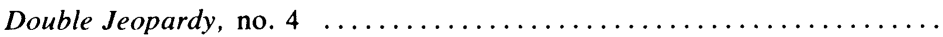

CHERMESH, Ran, Strikes as Safety-Valve Institutions no. $4 \ldots \ldots \ldots \ldots \ldots$

COTTELL, Philip L. and Richard T. BARTH, Factors Related to Performance Variation Among Logging-Machine Operators, no. $4 \ldots \ldots \ldots \ldots$

$379-396$

566-584

$452-456$

$65-94$

$603-619$

$161-172$

$340-377$

$108-127$

$547-563$

$532-545$

586-601

566-584 
D'AOUST, Claude, L'effet de la grève sur le contrat individuel de travail: l'affaire McGavin Toastmaster, no. 3

DWORKIN, James B. Final Position Arbitration and Intertemporal Compromise, no. 2

DYER, Lee D. et Roland D. THÉRIAULT, Critères d'augmentations de salaires chez les cadres canadiens-français, canadiens-anglais et américains, no. 1

FORTIN, Bernard et Bertrand BELZILE, Un modèle d'offre de travail des

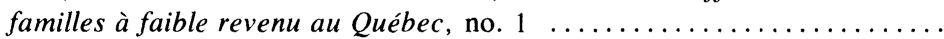

INGERMAN, Sidney $\mathrm{H}$. and Ruth ROSE-LIZÉE, The Estimate of Productivity Growth in Canada's Prices and Incomes Policy, no. 1 ........

JAIN, Harish C., Employee Pay and Benefit Preferences at Canadian

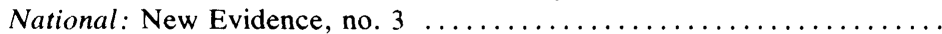

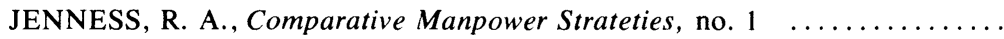

KASSALOW, E. M., Christian Trade Unionism in France: A Left Socialist

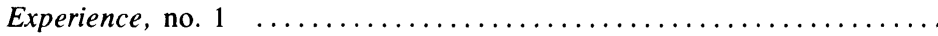

KOCHAN, Thomas A. and John C. ANDERSON, Collective Bargaining in the Public Service of Canada, no. 2

LAROUCHE, Viateur, Le développement des ressources humaines, fonction négligée par l'entreprise, no. 4

MANEGRE, Jean-François, Pierre-Paul PROULX et Luce BOURGAULT, Candide-Cofor et la prévision de besoins en main-d'euvre par occupation

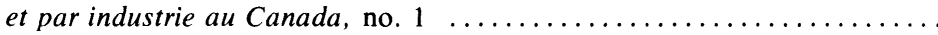

MEHMET, Ozay, Economic Returns on Under-Graduate Fields of Study in

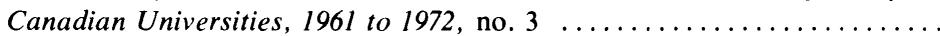

MIGUE, Jean-Luc, Salaire minimum ou quand le diable se fait moine, no. 3

MIKALACHKI, Al and D. C. CHAPPLE, Absenteeism and Overtime:

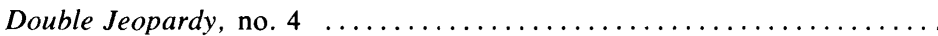

MORIN, Fernand, Divergence ou convergence du mouvement syndical et $d u$ mouvement coopératif des Caisses Desjardins, no. $2 \ldots \ldots \ldots \ldots \ldots$

MORIN, Fernand, L'injonction en temps de grève, no. $3 \ldots \ldots \ldots \ldots \ldots \ldots$

MONTMARQUETTE, Claude, Le contrôle et le décontrôle des prix et des revenus, no. 4

$449-452$

94-108

$234-250$

$483-511$

$108-127$

$321-337$

310-319

$532-545$

262-268

414-445

$628-634$

NEWTON, Keith, The Rationale for Government Involvement in Manpower

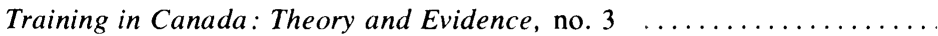

PECCEI, Riccardo and Malcolm WARNER, Towards "Participative" Multi-

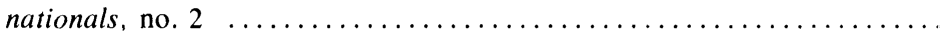

PEITCHINIS, Stephen, G., The Influence of Public Opinion in LabourManagement Relations and Dispute Settlement, no. $2 \ldots \ldots \ldots \ldots \ldots$

PROULX, Pierre-Paul, Luce BOURGAULT et Jean-François MANEGRE, Candide-Cofor et la prévision de besoins en main-d'auvre par occupa-

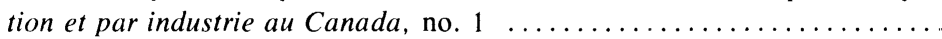

REID, Frank, The Response of Wages to the Removal of Controls: the

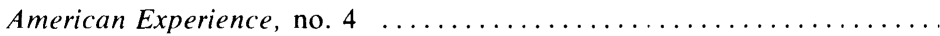

REID, Frank J. The Paradox of Unemployment and Job Vacancies. Comment,

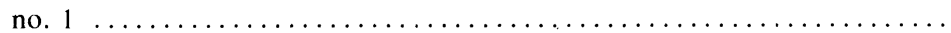

REID, Frank, Psychological Conflict Models: Their Applicability to the Theory of Collective Bargaining, no. 3

$399-414$

$172-184$

268-274

$108-127$

$621-628$

$133-137$

445-449 
ROSE, Joseph B. and Gary N. CHAISON, An Analysis of Annual Turnover Rates for Canadian Union Presidents, no. 4 ...................

ROSE, Joseph B, Construction Labour Relations Association in Canada,

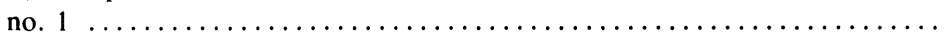

ROSE-LIZÉE, Ruth and Sidney H. INGERMAN, The Estimate of Productivity Growth in Canada's Prices and Incomes Policy, no. 1 ..............

ROUSSEAU, Henri-Paul, Un modèle de l'offre de travail des bénéficiaires

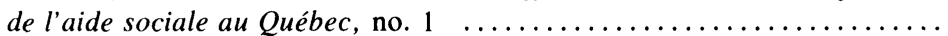

SENTES, Ray, Labour Arbitration and the Refusal to Perform Hazardous

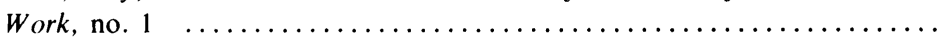

SIDDIQUI, Farid and Michael L. SKOLNIK, The Paradox of Unemployment

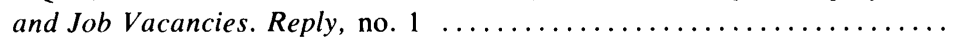

SKOLNIK, Michael L. and Farid SIDDIQUI, The Paradox of Unemployment

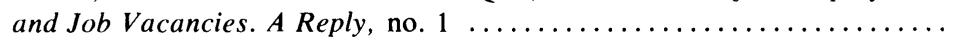

STURMTHAL, Adolf, Bullock and the Aftermath, no. $3 \ldots \ldots \ldots \ldots \ldots$

SUBBARAO, A. V., The Impact of the Two Dispute Resolution Processes

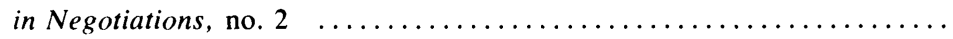

TANDON, B. B. and K. K. TANDON, Wage Differentials Between Native

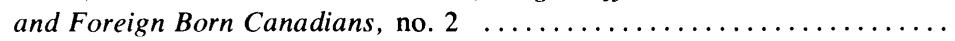

TANDON, K. K. and B. B. TANDON, Wage Differentials Between Native

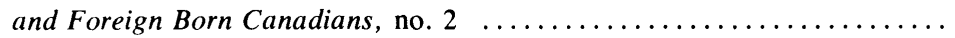

THÉRIAULT, Roland D. et Lee D. DYER, Critères d'augmentations de salaires chez les cadres canadiens-français, canadiens-anglais et amé-

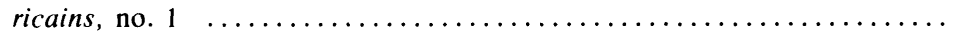

WALLOT, Hubert, La consultation: un processus andragogique centré sur

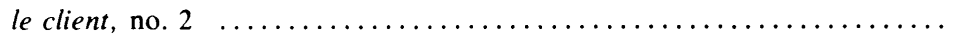

WARNER, Malcolm and Riccardo PECCEI, Towards "Participative" Multi-

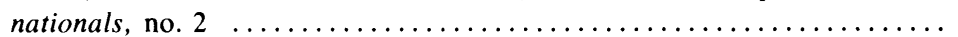

$547-563$

$35-50$

$127-133$

$50-65$

139-145

137-139

$137-139$

299-307

216-234

202-216

202-216

18-35

274-285

$172-184$

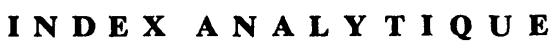 C U M U L A T I V E I N D E X \\ RELATIONS INDUSTRIELLES INDUSTRIAL RELATIONS
}

Volume 1 - Volume 25

(1945-1970)

\section{Rapport des - Proceedings of CONGRES DES RELATIONS INDUSTRIELLES}

(1946-1970)

\begin{abstract}
Avant-propos - Forewords; A- Index alphabétique - Subject index; B-1 Index méthodique - Broad Subject Headings Index; Liste des descripteurs génériques - List of generic keywords; B-2 Index méthodique des titres - Broad Subject Heading Index of Titles; C- Index methodique des ouvrages recensés - Broad Authors of Book Reviews; E- Auteurs des articles et des recensions - Authors of the Articles and Book Reviews; F- Róférences bibliographiques - Bibliographical References.

Un volume $6 \times 9$, relié, 360 pages prix : 10.00
\end{abstract}

En vente chez votre libraire ou chez l'éditeur

LES PRESSES DE L'UNIVERSITÉ LAVAL c.p. 2447, Québec 2, (Qué.) 